\title{
Changes in productivity associated with four introduced species: ecosystem transformation of a 'pristine' estuary
}

\author{
J. L. Ruesink ${ }^{1, *}$, B. E. Feist ${ }^{2}$, C. J. Harvey ${ }^{2}$, J. S. Hong ${ }^{3}$, A. C. Trimble ${ }^{1}$, L. M. Wisehart ${ }^{4}$ \\ ${ }^{1}$ Department of Biology, University of Washington, Box 35100, Seattle, Washington 98195-1800, USA \\ ${ }^{2}$ Northwest Fisheries Science Center, Fishery Resource Analysis and Monitoring Division, NOAA Fisheries, \\ 2725 Montlake Boulevard E, Seattle, Washington 98112-2097, USA \\ ${ }^{3}$ Department of Oceanography, Inha University, Incheon 402-751, Republic of Korea \\ ${ }^{4}$ Zoology Department, Oregon State University, Corvallis, Oregon 97331, USA
}

\begin{abstract}
Multiple stressors in estuaries can cause declines in native species and impairment of ecosystem goods and services. In contrast, one stressor - the introduction of non-native speciesactually leads to higher local richness. We examined the changes in ecosystem function associated with introductions into Willapa Bay, Washington, USA, a relatively undeveloped estuary with 45 documented exotic marine species. The replacement of native oysters by 2 new bivalve species has increased secondary production of harvested suspension feeders by $250 \%$ over peak historic values $\left(3.3 \times 10^{5}\right.$ vs. $0.9 \times 10^{5} \mathrm{~kg}$ dry wt $\left.\mathrm{yr}^{-1}\right)$, based on $>150 \mathrm{yr}$ of records of harvested biomass. Key aspects of aquaculture - particularly planted area - have remained constant over time, so we attribute much of the altered secondary production to higher growth rates of non-native species. The addition of 2 tracheophytes has increased primary production on the tideflats by $>50 \%\left(5.3 \times 10^{7} \mathrm{vs} .3 .5 \times 10^{7} \mathrm{~kg}\right.$ dry wt $\mathrm{yr}^{-1}$ ), which we calculated by scaling up local measurements of plant growth to the total area occupied by each species. These changes in production are also associated with altered detritus, water filtration, and biogenic habitat. Because other stressors are largely absent from Willapa Bay, the addition of particular exotic species has dramatically enhanced system production, while fundamentally reshaping the ecological character of the estuary. These strong ecological impacts of introduced species have rarely been measured at whole-ecosystem scales, and they occur in part because new species occupy habitats where similar native species were not present.
\end{abstract}

KEY WORDS: Crassostrea gigas $\cdot$ Invasion $\cdot$ Ostreola conchaphila $\cdot$ Spartina alterniflora $\cdot$ Ruditapes philippinarum $\cdot$ Zostera marina $\cdot$ Zostera japonica

Resale or republication not permitted without written consent of the publisher

\section{INTRODUCTION}

Many recent studies reveal a saturating relationship between ecosystem functions and species richness, with marginal change attributable to additional species when many others are already present (Hooper et al. 2005). In contrast, the addition of species through ecological invasion can cause dramatic change. Ecosystem functions are expected to be altered by exotic species that play entirely new roles in ecosystems (Shea \& Chesson 2002, Cuddington \& Hastings 2004), and some empirical examples exist (e.g. Myrica faya alters nutrient cycling in Hawaii where no native N-fixing plants occur; Vitousek \& Walker 1989). However, to date, ecologists have been presented with few opportunities to study whole-ecosystem impacts of introduced species. For instance, Parker et al. (1999) found just 18 examples of ecosystem-level impacts of invaders reported over a $10 \mathrm{yr}$ period, across all taxa and ecosystems, whereas impacts at individual, population, and community levels were studied more frequently ( $>90 \%$ of total). A unique opportunity arises in Willapa Bay, Washington, USA $\left(46^{\circ} 40^{\prime} \mathrm{N}, 124^{\circ} 0^{\prime} \mathrm{W}\right.$; surface area at mean sea level $=24000 \mathrm{ha})$, where 
lengthy time series and spatially explicit data allow reconstruction of primary production of tracheophytes and secondary production of bivalves over more than a century, during which period numerous nonindigenous species arrived. In this paper, we focus on 4 introduced species in Willapa Bay and document their contributions to primary and secondary production in the estuary. This case study illustrates 2 points: first, that gains in species - as much as species losses - can markedly influence whole-ecosystem functioning and therefore warrant the attention of predictive ecology and, second, that major changes in ecosystem functioning can be attributed to a few high-impact species rather than increases or decreases in numbers of species per se.

To set the stage for calculating whole-ecosystem changes and discussing their generality, we first present an ecological history of the bay. Willapa Bay is widely touted as pristine and productive (Wolf 1993, NOAA 1997), as it is largely unaffected by the pollution and coastal development that plague other estuaries. Chemical and nutrient pollution has historically been negligible, due to the sparse human population, minimal development in the watershed, and the absence of major industrial activities. About $30 \%$ of the 3500 ha of tidal marsh between mean high and extreme high water has been lost to diking for agriculture or expanding towns (Borde et al. 2003), but little other bathymetric modification has occurred since 1977 when maintenance dredging of the Willapa River channel ended (Hedgpeth \& Obrebski 1981). Sediment loads to the bay have likely varied over the past century of logging within the watershed (Hedgpeth \& Obrebski 1981, Kehoe 1982, Komar et al. 2004), and as a result of damming the Columbia River, the second largest river of the continental United States, which exits just south and often influences conditions at the bay's mouth (Simenstad et al. 1992, Peterson et al.
2000). The impacts of diking and sediment loading peaked by the mid-20th century and have since been constant or declined. The bay is also highly productive, as evidenced by its shellfish industry: although it is only $1 / 30$ the size of Chesapeake Bay on the east coast of the United States, nearly $10 \%$ of the United States' oysters are harvested there (US total $=16804$ metric tons shucked annually; Pritchard 2004), and shellfish production has contributed significantly to the local economy for $>150$ yr (Espy 1977). In contrast, over the same time period, oyster production on the east coast of the United States has dropped by $>90 \%$ (Kirby 2004), in part due to habitat degradation.

While its physical and chemical changes have been minimal (therefore remaining relatively 'pristine'), Willapa Bay has been biologically transformed by introduced species (Fig. 1). The tally now stands at 45 new plants, algae, and invertebrates (Wonham \& Carlton 2005), which comprise $>10 \%$ of the total estuarine biota (Ferraro \& Cole 2004). Two introduced taxa are particularly prominent: bivalve molluscs and aquatic tracheophyte plants. Pacific oysters Crassostrea gigas (Thunberg, 1793) were introduced to Willapa Bay in 1928 after native oysters Ostreola conchaphila (=Ostrea lurida) (Carpenter, 1857) were overexploited and transplants from eastern North America (Crassostrea virginica [Gmelin, 1791]) failed to thrive (Kincaid 1968). Early aquaculture activities involving these introduced oysters served as a vector for numerous other introductions (Carlton 1992).

The baseline bivalve community included thick accumulations of Ostreola conchaphila, covering up to $10 \%$ of the area of the bay, primarily in subtidal areas according to old charts (Collins 1892, Townsend 1896). O. conchaphila was commercially extinct by the early 20th century and, despite almost a century of low exploitation, remains rare in Willapa Bay (and throughout most of its range; Cook et al. 2000).
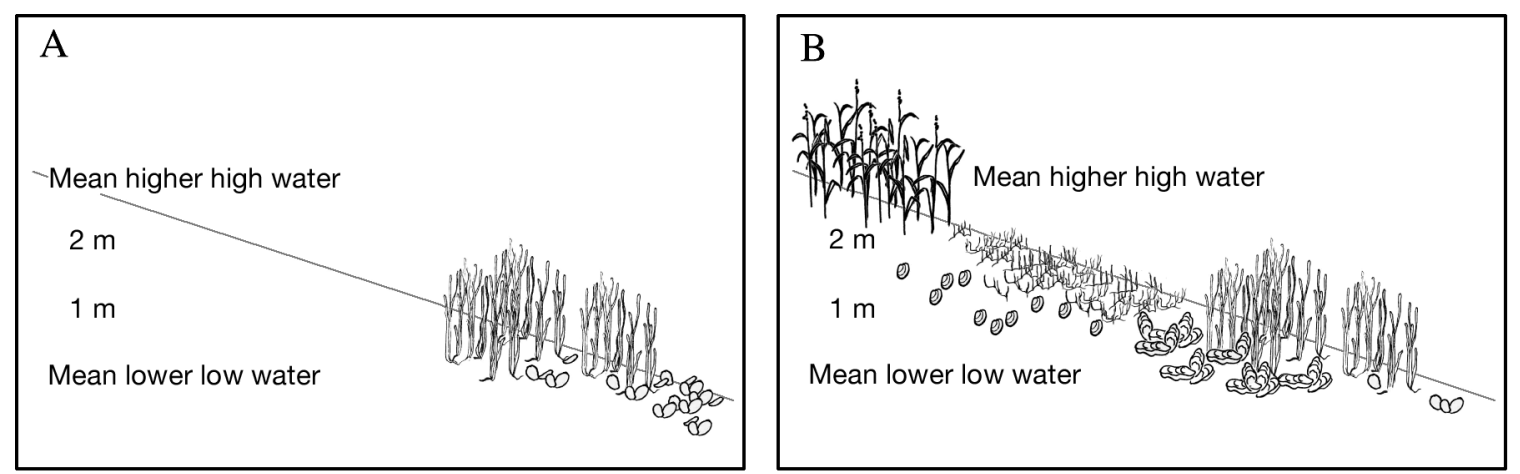

Fig. 1. Dominant space-occupying species on the tideflats of Willapa Bay. Vertical elevations (mean lower low water, $1 \mathrm{~m}$ above MLLW, $2 \mathrm{~m}$ above MLLW and mean higher high water) are provided to show where these species are found on tideflats. The slope of the tideflat (angled line) is exaggerated relative to field conditions. (A) Before 1900: native eelgrass Zostera marina and oysters Ostreola conchaphila. (B) After 2000: cordgrass Spartina alterniflora, Manila clams Ruditapes philippinarum, Japanese eelgrass Zostera japonica, and Pacific oysters Crassostrea gigas, in addition to native eelgrass and reduced densities of native oysters 
The introduced oyster Crassostrea gigas constitutes the bulk of oysters currently harvested from the bay (at least 3 other introduced oysters are planted in small numbers) and occurs in 2 habitats. In upper portions of the estuary, it recruits reliably and forms dense intertidal hummocks $\left(<1\right.$ to $\left.100 \mathrm{~m}^{2}\right)$ of tightly connected shell and live oysters. Many of these oysters are never harvested due to slow growth and irregular shapes. Nearer to the mouth, oysters are planted at relatively low densities directly on the bottom; oysters originate from natural recruitment elsewhere in the bay or from hatcheries.

A third bivalve, the Manila clam or Japanese littleneck Ruditapes (=Venerupis = Tapes) philippinarum (Adams \& Reeve, 1850) is now regularly harvested from the bay. Manila clams were introduced to the eastern Pacific as hitchhikers on Crassostrea gigas in 1936 (Carlton 1992); they are now cultivated on midintertidal flats. As with C. gigas, the distribution of Manila clams in Willapa Bay reflects both natural recruitment and planting. Little is known of the historic densities and distributions of other clams, although some insight comes from short periods of harvest records for introduced softshell clams Mya arenaria (Linnaeus, 1758) and for native razor clams Siliqua patula (Dixon, 1789) and littlenecks Protothaca staminea (Conrad, 1837). The 3 major harvested bivalve species allow a comparison, through historical records of yields, of the contributions to secondary production by native and introduced species.

Introduced oysters have been the vector of 2 plant species that occupy what were previously unvegetated mudflats (Fig. 1). The baseline condition for aquatic tracheophytes included native eelgrass Zostera marina (Linnaeus, 1753) in pools and extensive beds, generally at and just below mean lower low water (Borde et al. 2003). At upper tidal elevations, an invasive smooth cordgrass Spartina alterniflora (Loisel.) has increased rapidly over the past 2 decades, although its unintentional introduction occurred around 1890, presumably as discarded packing material for transplanted Crassostrea virginica (Townsend 1893, 1896, Feist \& Simenstad 2000). No native Spartina species occur in Willapa Bay, and $S$. alterniflora is considered a noxious weed in Washington State, with nearly \$2 million spent annually towards Spartina control. A small eelgrass species (Zostera japonica [Aschers. et Graebn.]) arrived on the British Columbia coast with transplanted C. gigas by 1957, but may have been in coastal Washington even earlier (Harrison \& Bigley 1982). In Willapa Bay, it now fills much of the tideflat between $Z$. marina and $S$. alterniflora. Ironically, Z. japonica in Washington state enjoys the same protection afforded the native species of eelgrass (Wonham 2003). These 3 plant species allow a comparison, through data on distribution and growth, of the contributions to primary production by native and introduced species.

We focus on 3 topics relating invasion and ecosystem functioning: (1) primary production by aquatic tracheophytes in Willapa Bay (1 native, 2 introduced species); (2) secondary production by bivalves in the bay (1 native, 2 introduced species); and (3) associated changes in biogenic habitat, detrital production, and filtration capacity. By compiling information from a variety of sources, we are able to estimate primary and secondary production by conspicuous species and how these have changed with the local rise in species richness accompanying introductions.

\section{MATERIALS AND METHODS}

Change in primary production in Willapa Bay. The area covered by the 2 eelgrass species was estimated from an unsupervised classification of a LANDSAT satellite image, acquired at low tide $(-0.307 \mathrm{~m}$ relative to mean lower low water [MLLW]) at 18:30 h GMT (Greenwich mean time) on 5 May 1997 (B. E. Feist \& C. A. Simenstad unpubl. data) (Fig. 2). Although it was possible to distinguish eelgrass beds of different density (dense vs. sparse) based on spectral differences, we did not use this information in our calculation of estuary-wide production, because our unit-production estimates came from a range of sites and eelgrass densities in the bay. Because it was not possible to distinguish the 2 species of Zostera in the LANDSAT image, we used additional groundtruthing data to determine coverage by each species. An independent assessment of habitat types was carried out by NOAA Coastal Services Center (NOAA CSC 2000) in 1997, which included 20 points within the area we classified as eelgrass and 74 outside. Commission errors were low: only 8 of 53 points without eelgrass were classified as eelgrass present. However, the LANDSAT image classification did miss considerable eelgrass, and only 12 of 41 points with eelgrass were classified as such. Overall, $60 \%$ of the points were classified correctly, with some bias towards underestimating total area of eelgrass (no correction to total area was attempted). We determined the percentage of georeferenced points observed to contain each species (55.5\% Z. marina, $44.4 \%$ Z. japonica) and multiplied the total area of eelgrass by the fraction represented by each species. For comparison, bathymetric considerations provide an estimate of 4845 ha potentially occupied by $Z$. marina in the 1950s, and 3139 ha, in the 1850s, when bay depths were lower on average (Borde et al. 2003). Our estimate of area covered by $Z$. marina fell within this range (3424 ha), likely at the lower end because other habitat types occupy some of the potential eelgrass zone ( 0 to $-1.2 \mathrm{~m}$ MLLW). 


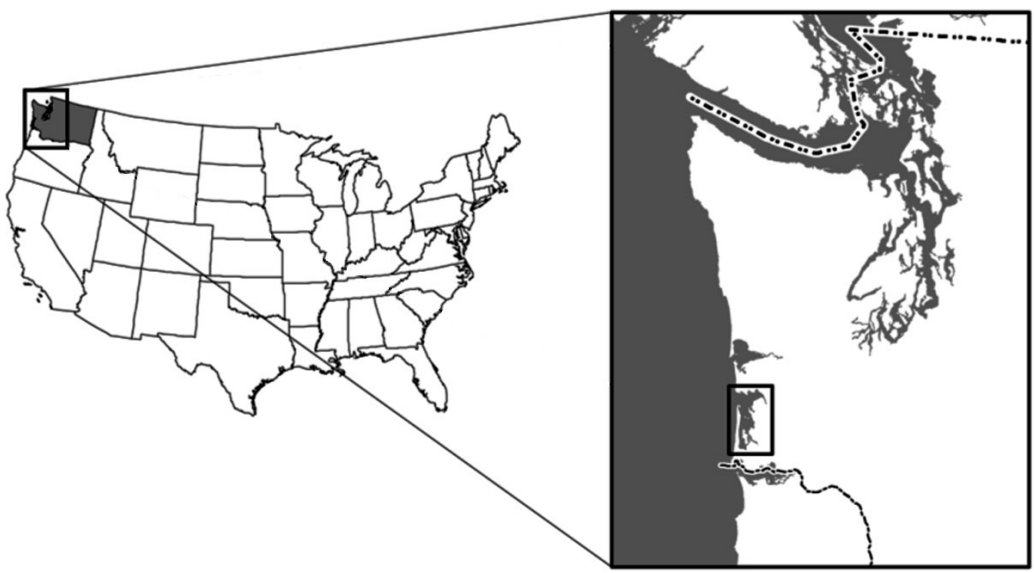

Fig. 2. Zostera marina and Z. japonica (left panel) and Spartina alterniflora (right panel). Distribution of dominant macrophyte species of Willapa Bay, ca. 1997. Inset shows location of Willapa Bay on the west coast of the United
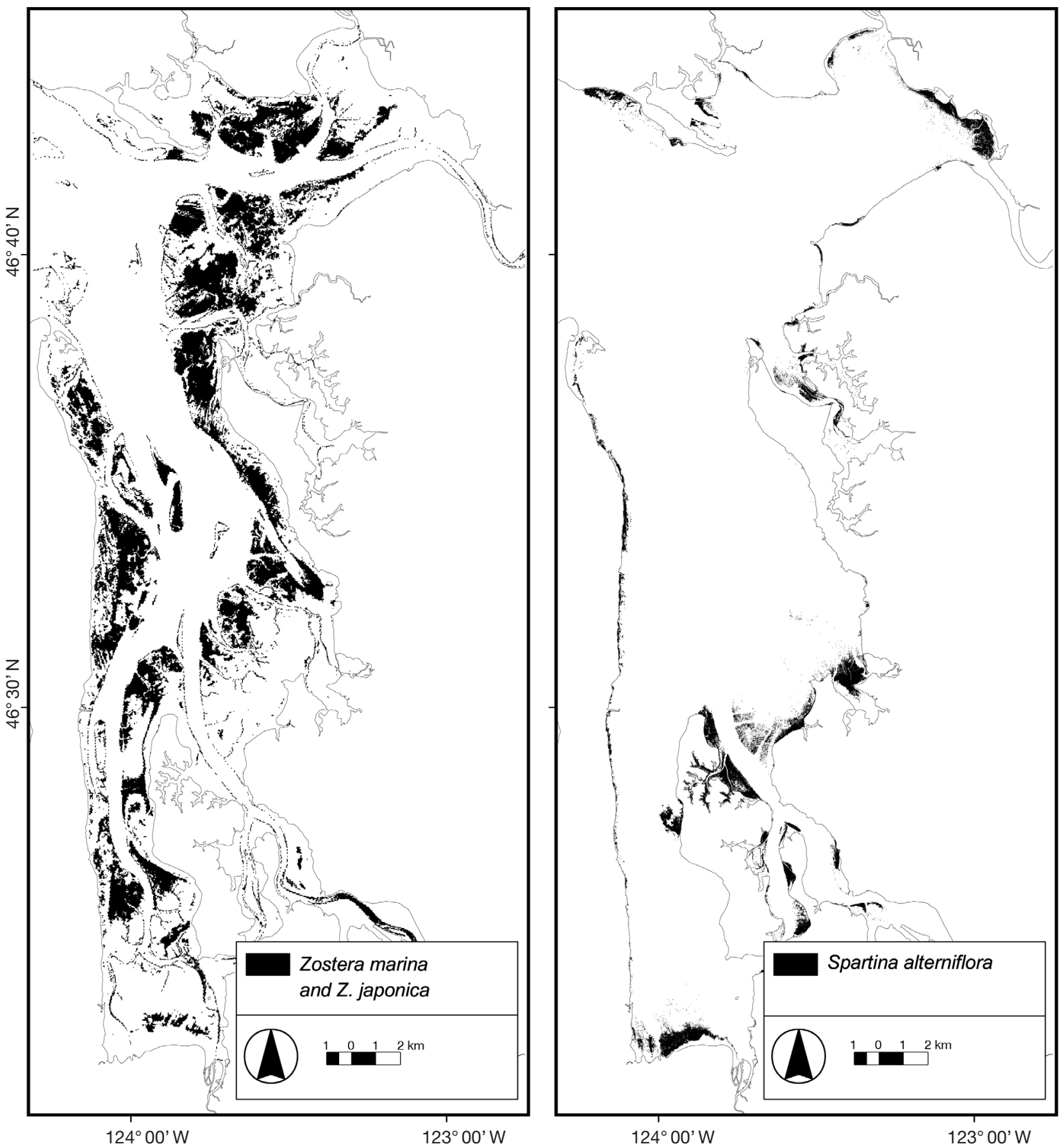
Annual production of Zostera marina on a unit-area basis was derived from shoot densities and growth measured seasonally at 7 locations spread across a distance of $20 \mathrm{~km}$ in Willapa Bay. Shoot density was based on the average shoot count in ten $0.25 \mathrm{~m}^{2}$ quadrats placed near 0 MLLW at each location. Adjacent to each quadrat, 5 shoots were pricked with an 18 gauge needle at the leaf sheath (Zieman \& Wetzel 1980). After 2 to 4 d, these shoots were collected, and growing leaves were separated into original (from needle mark to leaf tip) and new (from leaf sheath to needle mark) material and dried to constant weight at $60^{\circ} \mathrm{C}$. The masses of new material were averaged to estimate growth at each site. We measured shoot density and growth 4 times in 2004: winter (February), spring (early May), summer (late June), and autumn (early September). The product of shoot density and growth yielded unit-area production per day in each season. Annual unit-area production was calculated by extending daily measurements to each season, and summing across seasons. Obviously, these calculations require addition and multiplication that complicate calculations of error structure. To avoid problems associated with adding and multiplying error terms, we took a Monte Carlo approach. The entire calculation was repeated 100 times, each time selecting density and growth values at random from among the 7 locations for each season. From these 100 iterations, we calculated a mean and standard deviation. Finally we multiplied this unit-area annual production by the estimated area covered by $Z$. marina.

To assess annual production of Zostera japonica, we measured shoot densities and growth at 6 locations across $10 \mathrm{~km}$ in Willapa Bay: 3 locations were in the upper range occupied by $Z$. japonica, $+1.2 \mathrm{~m} \mathrm{MLLW,} \mathrm{and}$ 3 were at the lower end, $+0.6 \mathrm{~m}$ MLLW. Because $Z$. japonica blades are too narrow $(<1 \mathrm{~mm})$ for the holepunching technique, we instead used a comparable protocol (Kaldy 2006). Shoots were counted in nine $10 \mathrm{~cm}$ diameter areas at each sampling location. Growth was measured in 5 nearby $10 \mathrm{~cm}$ diameter areas, distinguished by PVC sleeves pushed $10 \mathrm{~cm}$ into the sediment and flush with the surface. We initially trimmed all shoots just above the leaf sheath. After $2 \mathrm{wk}$, shoots were again counted and trimmed, and the above-ground material was dried to constant weight at $60^{\circ} \mathrm{C}$. Growth rate was determined from the amount of new biomass relative to shoot number when the shoots were collected, divided by the number of days between initial and final trims. Because photosynthetic tissue was lost during the initial trim, regrowth may have slowed and growth rates are conservative (Ferraro \& Oesterheld 2002). Density and growth were sampled 5 times in 2004: March, May, July, September, and December. These measurements were extrapolated to 2 mo periods (except $4 \mathrm{mo}$ in winter). To estimate above- ground unit-area primary production, we selected values for density and growth at random from among the 6 locations at each time period. We multiplied density, growth, and the number of days in each season, then summed across seasons. This procedure was repeated 100 times to incorporate uncertainty. We calculated mean annual unit-area production (and standard deviation) from these 100 randomizations, then multiplied by the estimated tideflat area occupied by $Z$. japonica to generate a production estimate for the entire bay.

The Washington State Department of Natural Resources calculated the total solid area covered by Spartina alterniflora in Willapa Bay in 1997 using falsecolor infrared aerial photographs and ESRI ArcView shapefiles (WADNR 1999) (Fig. 2). This method slightly underestimated coverage because patches of $<1.36 \mathrm{~m}^{2}$ could not be detected. In contrast to eelgrass, cordgrass loses little of its production during the growing season, instead accumulating tissue above ground before dying back at the end of the year. Consequently, above-ground biomass per area served as a proxy for annual production; these values were available for Willapa Bay in Grevstad et al. (2003), as mean values for 3 locations. We multiplied this production per unit area by area covered by $S$. alterniflora to derive production for the whole bay.

Concerning other tracheophytes, no data are available for primary production in Willapa Bay's tidal marsh, which currently occupies 2484 ha between mean high water and extreme high water (Borde et al. 2003). Marsh plants have been replaced by terrestrial species in areas diked for grazing, but the more recent expansion of introduced aquatic tracheophytes has probably not further altered the contribution of high marsh to primary production in the bay-both introduced species grow below mean high water, whereas in Willapa Bay native marsh occurs above this level (Borde et al. 2003, Zhang et al. 2004, authors' pers. obs.).

Change in secondary production in Willapa Bay. We estimated annual production of the focal native bivalve (Ostreola conchaphila) and introduced bivalves (Crassostrea gigas and Ruditapes philippinarum) from aquaculture yields in Willapa Bay, as reported to the Washington Department of Fish and Wildlife (Fig. 3). Long-term average yields usually represent a minimum estimate of annual production, because the new biomass in each year must replace the biomass of bivalves removed by harvest. For each species, uncertainty in production was based on interannual variation over a period of 13 to 33 yr (arbitrarily selected as representative of sustained harvest levels), even though this variation may be due more to economic than to ecological conditions. Oyster yields were reported as pounds of shucked meat, which we converted to dry tissue mass by assuming a dry mass:fresh mass ratio of 0.22 (Kobayashi et al. 1997). Clam yields were reported as 


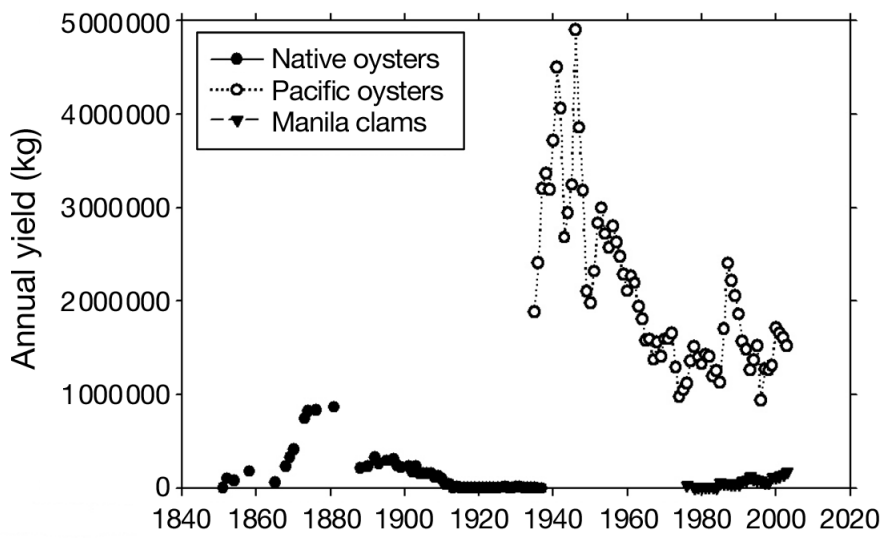

Fig. 3. Ostreola conchaphila, Crassostrea gigas, and Ruditapes philippinarum. Yields of bivalve species from Willapa Bay over 150 yr from Washington Department of Fish and Wildlife marine fish and shellfish landings annual reports. $O$. conchaphila (native oysters) and C. gigas (Pacific oysters) are displayed in units of shucked-meat weight (fresh), and $R$. philippinarum (Manila clams) in units of whole-clam weight

pounds in the shell, which we converted to dry tissue mass by assuming a dry mass:whole fresh mass ratio of 0.066 for 40 to $50 \mathrm{~mm}$ clams (Solidoro et al. 2003).

Historical trends of other bivalves are mostly unknown because poor records exist even for those species that are occasionally harvested. However, these harvest records for 1980 to 1991 suggest that other bivalves occurred at fairly low densities relative to oysters and Manila clams. For instance, native littlenecks Protothaca staminea and razor clams Siliqua patula averaged $1 \times 10^{4} \mathrm{~kg}$ live weight harvested per year, $\sim 10 \%$ of recent harvests of Manila clams (Fig. 3). Introduced softshell clams Mya arenaria were considered for a fishery in the late 1800 s, but populations declined abruptly before commercial exploitation began (Palacios et al. 2000).

Other ecosystem functions. Primary and secondary production in estuaries directly influence other ecosystem functions, such as habitat provision, inputs to detrital food webs, and water filtration. To assess changes in habitat, we focused on area occupied by native and introduced species. These data were readily available from LANDSAT and aerial photographs for tracheophytes (see 'Materials and methods Change in primary production in Willapa Bay'), but bivalves have not been similarly mapped. Both native and Pacific oysters recruit naturally in the southern part of Willapa Bay, due to warmer water temperatures and higher larval retention, but aquaculture primarily occurs closer to the mouth of the estuary, where growth rates are rapid (Ruesink et al. 2003).

All primary production was assumed to enter the detrital food web following senescence, because few herbivores consume eelgrass or cordgrass. In addition to changing detrital biomass, introduced species potentially influence both the timing and the quality (carbon:nitrogen ratio) of dead plant material. This matter may be a source of food or nutrients for some biota, and a source of disturbance to other biota sensitive to wrack burial. We have not quantified detritus fate, but offer a qualitative summary of information on eelgrassand cordgrass-derived detritus.

Filtration of Willapa Bay's water derives in part from cultured bivalves, and, consequently, we estimated filtration capacity based on secondary production. Filtration rates for each species were not measured directly in Willapa Bay, but a consistent relationship exists between size and filtration rate across many bivalve species (Powell et al. 1992). Consequently, we incorporated individual filtration rates of $3 \mathrm{l} \mathrm{h}^{-1}$ for Crassostrea gigas (100 mm, $2.4 \mathrm{~g}$ dry wt; Kobayashi et al. 1997) and $1 \mathrm{l} \mathrm{h}^{-1}$ for Ruditapes philippinarum (50 mm, $3.9 \mathrm{~g}$ dry $\mathrm{wt}_{\text {; }}$ Solidoro et al. 2003) and for Ostreola conchaphila (50 mm, $0.4 \mathrm{~g}$ dry wt; Brennan 1939). We determined the number of individuals of each bivalve species as the ratio of total harvest:individual biomass, and multiplied this estimate of density by per capita filtration rate. We then compared filtration by each species to the bay's total volume $\left(7.6 \times 10^{11} 1\right.$ at mean sea level; Hickey \& Banas 2003).

\section{RESULTS}

\section{Change in primary production in Willapa Bay}

The essential components for estimating primary production by aquatic tracheophytes in Willapa Bay included estimates of area occupied and annual production per area. Based on habitat classification from recent satellite images, each eelgrass species occupied about 3000 ha in Willapa Bay, and Spartina alterniflora occupied about 1300 ha in 1997 (Fig. 2). Annual rates of production per area were similar for S. alterniflora, based on peak standing biomass, and for Zostera marina based on seasonal measurements of growth rate $\left(\sim 1000 \mathrm{~g}\right.$ dry $\mathrm{wt} \mathrm{m}^{-2} \mathrm{yr}^{-1}$; Table 1$)$. These rates fall close to other published reports of net primary productivity for $S$. alterniflora (Dai \& Wiegert 1996) and $Z$. marina (Kentula \& McIntire 1986, Thom 1990). Production for $Z$. japonica, which reaches a high density but is a very small plant, was much lower $\left(\sim 170 \mathrm{~g}\right.$ dry wt $\mathrm{m}^{-2}$ $\left.\mathrm{yr}^{-1}\right)$, but was also similar to previous production estimates (Thom 1990).

We estimated that native eelgrass Zostera marina produced $>35000 \mathrm{t}$ of dry matter annually in Willapa Bay (Table 2). The 2 introduced species appear to have recently raised primary production by aquatic tracheophytes by $>50 \%$. The cordgrass Spartina alterniflora 
Table 1. Components of production by dominant macrophytes in Willapa Bay. Mean and standard deviation (SD) for shoot density and growth were calculated from $\mathrm{N}$ sites (in square brackets) throughout the bay. SD (in parentheses) for annual production per area of eelgrass was based on 100 Monte Carlo randomizations of values for each variable contributing to the calculation of annual production, specifically shoot growth and shoot density in different seasons

\begin{tabular}{|c|c|c|c|c|}
\hline \multirow[t]{2}{*}{ Species } & \multirow{2}{*}{$\begin{array}{l}\text { Area } \\
\text { (ha) }\end{array}$} & \multirow[t]{2}{*}{ Period } & \multicolumn{2}{|c|}{ Production per area } \\
\hline & & & $\begin{array}{l}\text { Shoot density } \\
\qquad\left(\mathrm{m}^{-2}\right)\end{array}$ & $\begin{array}{l}\text { Shoot growth } \\
\left(\mathrm{mg} \mathrm{dry} \mathrm{wt} \mathrm{shoot}^{-1} \mathrm{~d}^{-1}\right)\end{array}$ \\
\hline \multirow{5}{*}{$\begin{array}{l}\text { Zostera } \\
\text { marina }\end{array}$} & \multirow[t]{5}{*}{3423.6} & Winter & $161.7(30.4)[6]$ & $3.03(0.545)[5]$ \\
\hline & & Spring & $141.9(30.2)[7]$ & $24.3(9.18)$ \\
\hline & & Summer & 159.5 (33.9) [7] & $35.8(15.0)$ \\
\hline & & Autumn & $105.4(35.9)[7]$ & $14.9(4.19)$ \\
\hline & & Annual & \multicolumn{2}{|c|}{$\begin{array}{l}\text { Biomass, g dry wt m }{ }^{-2} \text { : } \\
1.03 \times 10^{3}\left(0.40 \times 10^{3}\right)\end{array}$} \\
\hline \multirow{6}{*}{$\begin{array}{l}\text { Zostera } \\
\text { japonica }\end{array}$} & \multirow[t]{6}{*}{2738.8} & Mar & $2242(1211)[6]$ & \multirow{5}{*}{$\begin{array}{l}0.0955(0.0200)[6] \\
0.2026(0.0529)[6] \\
0.2127(0.0667)[6] \\
0.1594(0.0607)[6] \\
0.0487(0.0178)[6]\end{array}$} \\
\hline & & May & 3271 (1718) [6] & \\
\hline & & Jul & $5996(1870)[6]$ & \\
\hline & & Sep & 3624 (2132) [6] & \\
\hline & & Dec & 1931 (653) [6] & \\
\hline & & Annual & \multicolumn{2}{|c|}{$\begin{array}{l}\text { Biomass, g dry wt m }{ }^{-2} \\
1.75 \times 10^{2}\left(0.51 \times 10^{2}\right)\end{array}$} \\
\hline $\begin{array}{l}\text { Spartina } \\
\text { alterniflora }\end{array}$ & 1298.5 & Annual & \multicolumn{2}{|c|}{$\begin{array}{l}\text { Biomass, g dry wt m }{ }^{-2}: \\
1.01 \times 10^{3}\left(0.49 \times 10^{3}\right)\end{array}$} \\
\hline
\end{tabular}

was estimated to produce an annual standing crop in excess of $13000 \mathrm{t}$, and the small-sized introduced eelgrass $Z$. japonica was estimated to produce nearly $4800 \mathrm{t}$, increases of 37 and $14 \%$, respectively. Considerable uncertainty exists around these average values, particularly due to spatial variation in shoot density (Table 1). However, the additional production estimated from introduced species exceeds the variation (standard deviation) within species.

\section{Change in secondary production in Willapa Bay}

Recent yields of Pacific oysters and Manila clams from Willapa Bay far outweigh historical landings of native oysters (Fig. 3, Table 2). The annual yield of introduced Crassostrea gigas at the end of the 20th century was almost 4 times higher than annual yields of native Ostreola conchaphila at the end of the 19th century. Venerupis philippinarum actually contributed little additional production, even though landings since 1985 have increased about $6 \%$ annually. We estimated that native oysters used to produce about $92 \mathrm{t}$ of dry matter annually, excluding shells. Secondary production from native oysters has largely disappeared, but introduced bivalves, particularly C. gigas, currently generate $330 \mathrm{t} \mathrm{yr}^{-1}$. Clearly, this secondary production is dwarfed by the primary production of aquatic tracheophytes, which have production values $>2$ orders of magnitude higher.

\section{Other ecosystem functions}

Habitat

Willapa Bay contains extensive intertidal flats, and, in the absence of introduced species, $39 \%$ of the bay's area would consist of unstructured intertidal habitat (Borde et al. 2003). In our spatial analyses, native Zostera marina occupied $9.6 \%$ of the bay's area (>3400 ha of 35700 ha; Table 1), and tidal flats have been modified by introduced Z. japonica (7.7\% of bay area) and Spartina alterniflora $(3.6 \%)$. Areas intensively cultivated for bivalves occupy $10 \%$ (Feldman et al. 2000), and, because both native and non-native species have been cultivated in these areas, we believe there has been little trend in cultivated area over the past century (Townsend 1896, Hedgpeth \& Obrebski 1981). However, wild populations of native Ostreola conchaphila were reportedly subtidal, accessible only at extreme low tides (Collins 1892), whereas hummocks of introduced Crassostrea gigas occur intertidally (authors' pers. obs.). Thus, oyster habitat has shifted from sub-tidal to intertidal areas where oysters recruit naturally, but precise dimensions are not available.

Table 2. Estimated annual production (prod.) by dominant macrophyte and bivalve species in Willapa Bay. No sample sizes (N) are provided for primary production because SD (in parentheses) was based on Monte Carlo randomizations. For secondary production, $\mathrm{N}$ (in brackets) is number of years of sustained harvests

\begin{tabular}{|c|c|c|c|c|}
\hline \multirow[t]{2}{*}{ Species } & \multirow{2}{*}{$\begin{array}{l}\text { Native/ } \\
\text { Introduced }\end{array}$} & \multicolumn{2}{|c|}{ Years of measurements } & \multirow{2}{*}{$\begin{array}{c}\text { Annual production } \\
\left(\mathrm{kg} \text { dry wt } \mathrm{yr}^{-1}\right)\end{array}$} \\
\hline & & Area & Prod. & \\
\hline Zostera marina & Native & 1997 & 2004 & $3.53 \times 10^{7}\left(1.37 \times 10^{7}\right)$ \\
\hline Zostera japonica & Introduced & 1997 & 2004 & $4.79 \times 10^{6}\left(1.40 \times 10^{6}\right)$ \\
\hline Spartina alterniflora & Introduced & 1997 & 2001 & $1.31 \times 10^{7}\left(0.63 \times 10^{7}\right)$ \\
\hline Ostreola conchaphila & Native & \multicolumn{2}{|c|}{$1866-1900$} & $9.16 \times 10^{4}\left(0.54 \times 10^{4}\right)[16]$ \\
\hline Crassostrea gigas & Introduced & \multicolumn{2}{|c|}{$1971-2003$} & $3.23 \times 10^{5}\left(0.72 \times 10^{5}\right)[33]$ \\
\hline Ruditapes philippinarum & Introduced & \multicolumn{2}{|c|}{$1991-2003$} & $6.94 \times 10^{3}\left(0.22 \times 10^{3}\right)[13]$ \\
\hline
\end{tabular}


These new habitats influence the entire community composition of smaller estuarine organisms. For instance, epibenthic organisms are more diverse on $C$. gigas than in open mudflats (Hosack 2003). Estuarine invertebrates respond to $S$. alterniflora and $Z$. japonica in complicated ways: some species increase and some decline relative to nearby mudflats, but, as with oysters, the overall effect is to alter community structure (Posey 1988, Wonham 2003).

\section{Detritus}

The calculated increase in the bay's macrophyte production over the past century due to invaders likely had a concomitant effect on detritus. In addition to the overall increase in detrital biomass (>50\%), both the type and timing of detrital production have changed. Zostera japonica detritus has a lower C:N ratio (C. J. Harvey unpubl. data) and more rapid decomposition than the native eelgrass (Hahn 2003). In contrast, Spartina alterniflora has a higher C:N ratio than $Z$. marina (C. J. Harvey unpubl. data). Rather than producing detritus throughout the growing season, $S$. alterniflora accumulates biomass, and detritus appears in autumn. In Willapa Bay, wrack builds up substantially on beaches, where its effects on plant regeneration and invertebrate communities are presumably similar to those in its native range (Ranwell 1967, McCaffrey 1976). Wrack-burial disturbance has been shown to alter salt marsh structure (Boston 1983), plant zonation and community structure (Brewer et al. 1998, Pennings \& Richards 1998), sediment chemistry (Pennings \& Richards 1998), and plant clonal morphology (Brewer \& Bertness 1996). Prior to the arrival of $S$. alterniflora, Willapa Bay was not subjected to heavy annual inputs from wrack generated by marsh plant dieback.

\section{Filtration}

The filtration capacity of bivalves can substantially influence the overall state of an estuary (Jackson et al. 2001). Scaling up to annual yields, we estimated that native oysters could have filtered $6.0 \times 10^{9} \mathrm{l} \mathrm{d}^{-1}$ prior to exploitation, and the 2 introduced bivalves filter at least $9.7 \times 10^{9} \mathrm{ld}^{-1}$. Daily, these respective rates would affect 0.8 and $1.3 \%$ of the bay's volume $\left(7.6 \times 10^{11} \mathrm{l}\right.$ at mean sea level; Hickey \& Banas 2003). Although these percentages appear small, they only account for feeding by harvested bivalves, leaving out unreported collections, beds where bivalves have not reached market size, feral populations, and other suspension-feeding species. The calculated difference in historic and cur- rent filtration rates is less than the difference in yield, because smaller individuals (e.g. native oysters) have higher per biomass filtration than larger individuals (e.g. Pacific oysters).

\section{DISCUSSION}

\section{Primary and secondary production in heavily invaded estuaries}

As new species entered Willapa Bay over the past century, total primary production by focal aquatic tracheophytes increased by $>50 \%$, and total secondary production by focal bivalves increased by $250 \%$, despite the decline of the native oyster (Table 2). In fact, we have likely underestimated change in secondary production: harvested biomass was not sustainable for native oysters, suggesting it overestimates historical production, whereas introduced oysters and clams occur in feral populations outside aquaculture, and harvested biomass likely underestimates current production. Of course, these calculations for macrophytes and bivalves include just 1 native and 2 introduced species in each case, and they do not account for diverse additional native and non-native species. However, it is extremely unusual to know wholeecosystem production for even 6 species, and the contributions from other bivalves and tracheophytes appear to be small and/or relatively stable over the past 50 yr (see 'Materials and methods').

More generally, none of the introduced species we examined fully occupies its potential habitat in Willapa Bay, so there may be capacity for further increases in production. Such is particularly true of tracheophytes, which continue to expand rapidly. In 2000 relative to 1997, the area of Spartina alterniflora in Willapa Bay increased by $23 \%$ (to 1601 ha; WADNR 2003). Given a total intertidal area of 18200 ha, perhaps half of which is potentially invasible by cordgrass, annual production could increase by up to 6-fold if left uncontrolled. According to analyses by Pacific County (in Hedgpeth \& Obrebski 1981), oyster yields (and therefore secondary production) could be enhanced by an order of magnitude, although oyster expansion is constrained by the availability of settlement substrate, and will lag behind expansion of tracheophytes unless there are changes in aquaculture practices. Furthermore, recent oceanographic models of the bay indicate that increased biomass could come at the expense of slowed individual growth rates (N. S. Banas et al. unpubl. data).

The introduced species considered here have modified production, and likely a variety of other ecosystem processes, because they consist disproportionately of ecosystem engineers (Jones et al. 1994, Gutierrez et al. 
2003, Cuddington \& Hastings 2004). Both macrophytes and oysters provide biogenic structure and modify their local environment in self-reinforcing ways, for instance by accumulating sediment (Spartina alterniflora; Zipperer 1996) or providing hard substrate for recruitment (oysters; Mobius 1883). The introduced species of bivalves and tracheophytes in Willapa Bay may play particularly high-impact roles, because these tideflats were previously unstructured (Fig. 1), and the new species do not simply replace native species, which tend to be restricted to different tidal elevations. The previously unstructured mudflats certainly supported other primary producers and filter feeders in the past. Given our reliance on harvest records and remote-sensing data to estimate production for even the most prolific introduced species, we cannot make quantitative estimates of production changes for benthic diatoms, small native bivalves, burrowing shrimp, or other filter- or deposit-feeding infauna. Nor can we conclude how the production rates of organisms associated with new substrates (e.g. benthic diatoms, macroalgae, and filter feeders living on oyster shell substrates; epiphytes living on Zostera japonica) compare with rates on open mudflats without further study.

Ecological theory suggests that environments with free resources (empty niches) are particularly susceptible to invasion (Shea \& Chesson 2002), and new species that modify their environment to their own benefit have particularly high impacts (Crooks 2002, Cuddington \& Hastings 2004). Our data directly indicate how species that play novel roles in an ecosystem can affect production, with further implications for habitat, detritus, and filtration. For example, Crassostrea gigas reefs and culture sites provide extensive, otherwise unavailable hard substrate for fish, invertebrates, and macroalgal species such as Ulva spp. and Enteromorpha spp., both of which have become abundant in intertidal zones where $C$. gigas culture or hummocks are present. In addition, Willapa's introduced engineers probably also affect biogeochemical cycles. In another coastal estuary, introduced Zostera japonica serves as a sink for water-column nutrients (Larned 2003), and bivalves can store nutrients in biodeposits (Chapelle et al. 2000), or, at high densities, enhance nutrient release (Bartoli et al. 2001). Furthermore, oyster expansion has occurred at the expense of burrowing shrimp and other infauna, undoubtedly causing changes in sediment porosity and bioturbation and further affecting biogeochemistry (Webb \& Eyre 2004).

The Willapa Bay case history is also compelling, because similar shifts in ecosystem function are likely occurring in other tideflat-dominated estuaries where these and other introduced species have become established (e.g. Cohen \& Carlton 1995, Castillo 2000). We expect that this same suite of introduced species will have, or is already having, similar effects in other estuaries in the region, many of which have comparable native taxa, aquacultural practices, geological ages, tidal amplitudes, and sediment-accretion rates (e.g. Emmett et al. 2000), and often much greater levels of human activity and anthropogenic disturbance. It is possible to imagine additional engineering species that could further transform west coast tideflats, such as burrowing fiddler crabs (e.g. McCraith et al. 2003).

\section{Biodiversity-ecosystem function relationships for native and non-native species}

Most conceptual models and much empirical data about the relationship between biodiversity and ecosystem functioning portray a linear or asymptotic curve (Hooper et al. 2005). In native systems, we expect ecosystem processes to asymptote as species richness increases, due to competition for and partitioning of space and other resources among functional group members. In contrast, in invasion biology, it is well recognized that a small proportion of introduced species have disproportionately high impacts (Williamson \& Fitter 1996). Thus, the expansion of primary producers and filter feeders higher into the intertidal zone of Willapa Bay represents a step change in several major ecosystem processes. A small number of highly successful invaders has dramatically altered ecosystem processes even though species richness increased only slightly (Fig. 4). Such step functions are by-products of the invaders' typically high rates of productivity, fecundity, and dispersal relative to the native community (Mack et al. 2000), particularly if they play a novel ecosystem role. Additionally, inherent differences between closely related native and introduced species can magnify the impact of the introduction; in the present case, the total area occupied by Crassostrea gigas under cultivation $(\sim 10 \%$ of bay area; Feldman et al. 2000) probably does not greatly exceed the historical area of native oysters. However, there are profound

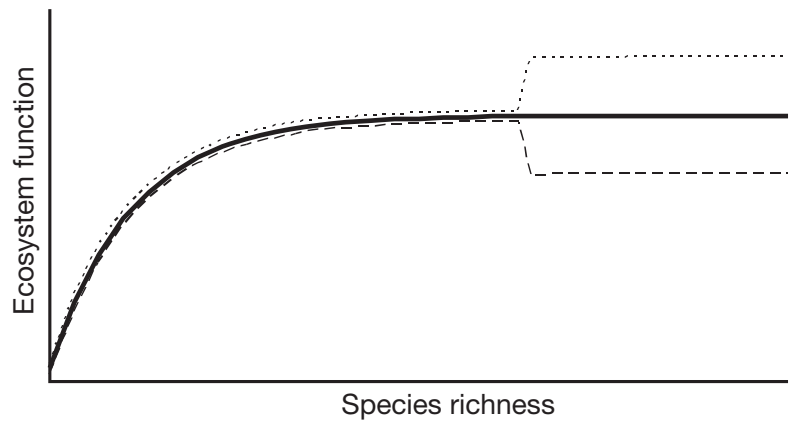

Fig. 4. Step change in ecosystem functioning associated with the introduction of a high-impact species to an otherwise intact ecosystem 
biological differences between the 2 oyster species that drastically affect their ecological impacts: C. gigas grows several times faster (Ruesink et al. 2005, A. C. Trimble et al. unpubl. data), reaches a larger maximum size (30 vs. 6 cm; Baker 1995), and has greater desiccation and temperature tolerance (Korringa 1976) than Ostreola conchaphila. These 2 branches of thought in community ecology - one emphasizing the role of species or functional group richness and the other emphasizing the high impacts of particular species - remain unreconciled.

Three considerations may help reconcile research focused on biodiversity versus invasion: scale, trophic complexity, and real differences in how native and non-native species affect ecosystem processes. The 'scale' issue reflects methodological differences: biodiversity-ecosystem function studies have been carried out by comparing species richness across sites or experimentally manipulating the number of species locally (Stachowicz et al. 2002, Duffy et al. 2003, Raffaelli et al. 2003), generally by random removal of species (but see Solan et al. 2004). Invasion biology tends to emphasize impacts at the level of a site, and there is by necessity biased selection of study species that have high impacts. Thus, invasion biologists find that particular species matter because that is the hypothesis they test. Trophic complexity is generally low in biodiversity-ecosystem function studies, where suites of species compete for a common resource. In contrast, many high-impact invaders are consumers and thus introduce new trophic roles into a community. It should be noted, however, that studies of multiple trophic levels of native species have also shown that consumer impacts can trump species richness in determining production (Paine 2002). So, different amounts of trophic complexity incorporated in study design may also explain differing results. Finally, it is possible that native species with a long history of coevolution do indeed interact differently than nonnatives entering a novel recipient community. This leads to the expectation that, while both native and non-native species can influence ecosystem processes, native species do so primarily through resource use efficiency and non-natives through sampling effects. Resource use efficiency would be expected in a group of species that has had the opportunity to adapt, specialize, and partition resources (Ruesink \& Srivastava 2001). In contrast, in newly introduced species, production might improve primarily through a sampling effect, because a small proportion of exotics strongly influences ecosystem functioning. A major research need is for small-scale studies that explicitly address patterns of production across richness levels of native species versus natives and non-natives combined.
Because the Willapa Bay community has been irreversibly altered, it is difficult to reconstruct the biodiversity-ecosystem function relationship for native species alone. However, the tremendous amount of habitat available to invasion makes it very likely that step functions have occurred in functions such as primary production, detritus generation, filtration, and sediment-water exchanges (Fig. 4). These step functions derive from gains in species, rather than from losses. Some previously important species have declined in abundance, but none has been eliminated entirely. Evidence from other systems suggests more attention should be paid to ecosystem responses as species invade. Outside of islands and lakes, introduced species rarely cause outright extinction, although they often change the relative abundance of species and therefore diversity (Wilcove et al. 1998, Gurevitch \& Padilla 2004). Consequently, local invasions exceed extinctions for many taxa (Sax et al. 2002), and theory also suggests that global biotic homogenization will tend to enhance local richness (Rosenzweig 2000).

\section{Management response}

Changes in production in Willapa Bay have had substantial economic consequences, as well as ecological. In general, management is directed at fostering the production of bivalves and reducing the production of tracheophytes (even though these species all provide valuable ecosystem functions where they are native). Introduced Spartina alterniflora is targeted for control with herbicides, estimated at about 40001 of imazapyr in 2004 (Hedge et al. 2003, Patten 2003). In contrast, introduced bivalves are planted for economic benefit, which on a local scale precludes production by other species. Dredging during oyster culture can remove native eelgrass, which is protected under a Washington state policy of no net loss (Pawlak \& Olson 1995), and pesticides (2000 kg of carbaryl annually around 1990; WDF/WDOE 1992) are sprayed to kill native burrowing shrimp Neotrypaea californiensis (Dana, 1854), a 'pest' species that displaces eelgrass and smothers oysters (Feldman et al. 2000, Dumbauld \& Wyllie-Echeverria 2003).

Within taxa, management also differs. At the same time that millions of dollars are being spent on Spartina control, Zostera japonica, another introduced macrophyte in a similar habitat, is protected in Washington (Wonham 2003). Our analysis suggests that the discrepancy stems in part from $S$. alterniflora's higher production and therefore impact in Willapa Bay (Table 2). Similarly, introduced species of oysters and clams are being farmed in preference to native species. Here too, relative productivity may weigh heavily in aquaculturists' decisions (Table 2). 
The lesson from Spartina alterniflora and Zostera japonica is that alterations of the food web can cause management problems, which are difficult to reverse. New species should be introduced with caution, and spread of established invasive plants should be controlled. The lesson from Crassostrea gigas and Ruditapes philippinarum is that careful planting (preventing overexploitation) and protection of water quality can result in sustained estuarine resources for humans. While these bivalves cannot be eliminated, due to their economic importance and widespread distribution, it is possible that many feral oysters could be removed and native oysters could be restored in subtidal areas. Humans depend on the productivity of the earth's living systems, including estuarine ecosystems, and they also transform the local species involved in production, both intentionally and unintentionally, through introductions. The challenge facing managers is to determine cumulative risk, where the impacts of introduced species on native species, estuarine biodiversity, and ecosystem function are viewed in the context of all the perturbations, natural and anthropogenic, that affect estuaries.

Acknowledgements. Estimates of eelgrass primary production were collected with help from S. Bradley, B. Dumbauld, S. Hacker, L. McCoy, E. L. Wagner, and J. M. White. We gratefully acknowledge the Washington Department of Fish and Wildlife, particularly B. Kauffman, for providing data on shellfish harvests. Our research in Willapa Bay would have been impossible without intertidal access granted by the following shellfish growers: Coast Seafoods, Northern Oyster, Oysterville Sea Farms, Taylor Shellfish, and Wiegardt Brothers Jolly Roger Oysters. Funding for portions of this research was provided by USDA Western Regional Aquaculture Center (to J.L.R.) and the Andrew W. Mellon Foundation (to J.L.R. and A.C.T.). The ideas in this paper are those of the authors and do not represent positions of their employers or funding agencies.

\section{LITERATURE CITED}

Baker P (1995) Review of ecology and fishery of the Olympia oyster, Ostrea lurida, with annotated bibliography. J Shellfish Res 14:501-518

Bartoli M, Nizzoli D, Viaroli P, Turolla E, Castaldelli G, Fano EA, Rossi R (2001) Impact of Tapes philippinarum farming on nutrient dynamics and benthic respiration in the Sacca di Goro. Hydrobiologia 455:203-212

Borde AB, Thom RM, Rumrill S, Miller LM (2003) Geospatial habitat change analysis in Pacific Northwest coastal estuaries. Estuaries 26:1104-1116

Boston KG (1983) The development of salt pans on tidal marshes, with particular reference to south-eastern Australia. J Biogeogr 10:1-10

Brennan W (1939) Forty-sixth to forty-ninth, inclusive, annual reports of the state Department of Fisheries, state of Washington, Dept. of Fisheries, Olympia, WA

Brewer JS, Bertness MD (1996) Disturbance and intraspecific variation in the clonal morphology of salt marsh perennials. Oikos 77:107-116
Brewer JS, Levine JM, Bertness MD (1998) Interactive effects of elevation and burial with wrack on plant community structure in some Rhode Island salt marshes. J Ecol 86: $125-136$

Carlton JT (1992) Introduced marine and estuarine mollusks of North America: an end-of-the-20th century perspective. J Shellfish Res 11:489-505

Castillo GC (2000) Benthic biological invasions in two temperate estuaries and their effects on trophic relations of native fish and community stability. PhD thesis, Oregon State University, Corvallis, OR

Chapelle A, Menesguen A, Deslous-Paoli JM, Souchu P, Mazouni N, Vaquer A, Millet B (2000) Modelling nitrogen, primary production and oxygen in a Mediterranean lagoon. Impacts of oysters farming and inputs from the watershed. Ecol Model 127:161-181

Cohen, AN, Carlton JT (1995) Nonindigenous aquatic species in a United States estuary: a case study of the biological invasions of the San Francisco Bay and Delta. United States Fish and Wildlife Service, Washington, DC

Collins JW (1892) Report of the commissioner for 1888, United States Commission of Fish and Fisheries. Government Printing Office, Washington, DC

Cook AE, Shaffer JA, Dumbauld BR, Kauffman BE (2000) A plan for rebuilding stocks of Olympia oysters (Ostreola conchaphila, Carpenter, 1857) in Washington State. J Shellfish Res 19:409-412

Crooks JA (2002) Characterizing ecosystem-level consequences of biological invasions: the role of ecosystem engineers. Oikos 97:153-166

Cuddington K, Hastings A (2004) Invasive engineers. Ecol Model 178:335-347

Dai T, Wiegert RG (1996) Estimation of the primary productivity of Spartina alterniflora using a canopy model. Ecography 19:410-423

Duffy JE, Richardson JP, Canuel EA (2003) Grazer diversity effects on ecosystem functioning in seagrass beds. Ecol Lett 6:637-645

Dumbauld BR, Wyllie-Echeverria S (2003) The influence of burrowing thalassinid shrimps on the distribution of intertidal seagrasses in Willapa Bay, Washington, USA. Aquat Bot 77:27-42

Emmett R, Llanso R, Newton J, Thom R and 5 others (2000) Geographic signatures of North American West Coast estuaries. Estuaries 23:765-792

Espy WR (1977) Oysterville. University of Washington Press, Seattle, WA

Feist BE, Simenstad CA (2000) Expansion rates and recruitment frequency of exotic smooth cordgrass, Spartina alterniflora (Loisel), colonizing unvegetated littoral flats in Willapa Bay, Washington. Estuaries 23:267-274

Feldman KL, Armstrong DA, Dumbauld BR, DeWitt TH, Doty DC (2000) Oysters, crabs, and burrowing shrimp: review of an environmental conflict over aquatic resources and pesticide use in Washington State's (USA) coastal estuaries. Estuaries 23:141-176

Ferraro SP, Cole FA (2004) Benthic macrofaunal aliens in Willapa Bay (Poster). Pacific Estuarine Research Society annual meeting, May 18, 2004, Port Townsend, Washington

Ferraro DO, Oesterheld M (2002) Effect of defoliation on grass growth: a quantitative review. Oikos 98:125-133

Grevstad FS, Strong DR, Garcia-Rossi D, Switzer RW, Wecker MS (2003) Biological control of Spartina alterniflora in Willapa Bay, Washington, using the planthopper Prokelisia marginata: agent specificity and early results. Biol Control 27:32-42 
Gurevitch J, Padilla DK (2004) Are invasive species a major cause of extinctions? Trends Ecol Evol 19:470-474

Gutierrez JL, Jones CG, Strayer DL, Iribarne OO (2003) Mollusks as ecosystem engineers: the role of shell production in aquatic habitats. Oikos 101:79-90

Hahn DR (2003) Alteration of microbial community composition and changes in decomposition associated with an invasive intertidal macrophyte. Biol Invest 5:45-51

Harrison PG, Bigley RE (1982) The recent introduction of the seagrass Zostera japonica Aschers. \& Graebn. to the Pacific Coast of North America. Can J Fish Aquat Sci 39:1642-1648

Hedge P, Kriwoken LK, Patten K (2003) A review of Spartina management in Washington State, U.S. J Aquat Plant Manag 41:82-90

Hedgpeth JW, Obrebski S (1981) Willapa Bay: a historical perspective and a rationale for research. FWS/OBS-81/03, Office of Biological Services, U.S. Fish and Wildlife Service, Washington, DC

Hickey BM, Banas NS (2003) Oceanography of the U.S. Pacific Northwest coastal ocean and estuaries with application to coastal ecology. Estuaries 26:1010-1031

Hooper DU, Chapin FS III, Ewel JJ, Hector A and 11 others (2005) Effects of biodiversity on ecosystem functioning: a consensus of current knowledge. Ecol Monogr 75:3-35

Hosack G (2003) Effects of Zostera marina and Crassostrea gigas culture on the intertidal communities of Willapa Bay, Washington. MS thesis, University of Washington, Seattle, WA

Jackson JBC, Kirby MX, Berger WH, Bjorndal KA and 15 others (2001) Historical overfishing and the recent collapse of coastal ecosystems. Science 293:629-638

Jones CG, Lawton JH, Shachak M (1994) Organisms as ecosystem engineers. Oikos 69:373-386

Kaldy JE (2006) Production ecology of the non-indigenous seagrass, dwarf eelgrass (Zostera japonica Ascher. \& Graeb.), in a Pacific Northwest estuary, USA. Hydrobiologia 553:201-217

Kehoe DM (1982) Sources of sediment to Grays Harbor estuary. U.S. Army Corps of Engineers, Seattle, Washington

Kentula ME, McIntire CD (1986) The autecology and production dynamics of eelgrass (Zostera marina L.) in Netarts Bay, Oregon. Estuaries 9:188-199

Kincaid T (1968) The ecology of Willapa Bay, Washington, in relation to the oyster industry. Kincaid (self-published), Seattle, WA

Kirby MX (2004) Fishing down the coast: historical expansion and collapse of oyster fisheries along continental margins. Proc Natl Acad Sci 101:13096-13099

Kobayashi M, Hofmann EE, Powell EN, Klinck JM, Kusaka K (1997) A population dynamics model for the Japanese oyster, Crassostrea gigas. Aquaculture 149:285-321

Komar PD, McManus J, Styllas M (2004) Sediment accumulation in Tillamook Bay, Oregon: natural processes versus human impacts. J Geol 112:455-469

Korringa P (1976) Farming the flat oysters of the genus Ostrea: a multidisciplinary treatise. Elsevier Scientific, Amsterdam

Larned ST (2003) Effects of the invasive, nonindigenous seagrass Zostera japonica on nutrient fluxes between the water column and benthos in a NE Pacific Estuary. Mar Ecol Prog Ser 254:69-80

Mack RN, Simberloff D, Lonsdale WM, Evans H, Clout M, Bazzaz FA (2000) Biotic invasions: causes, epidemiology, global consequences, and control. Ecol Appl 10:689-710

McCaffrey CA (1976) The major vegetation communities of the Virginia Coast Reserve. In: The Virginia Coast Reserve study, Vol I. The ecosystem description. The Nature Conservancy, Arlington, VA

McCraith BJ, Gardner LR, Wethey DS, Moore WS (2003) The effect of fiddler crab burrowing on sediment mixing and radionuclide profiles along a topographic gradient in a southeastern salt marsh. J Mar Res 61:359-390

McLusky DS, Martins T (1998) Long-term study of an estuarine mudflat subjected to petro-chemical discharges. Mar Pollut Bull 36:791-798

Mobius K (1883) The oyster and oyster-culture. In: United States Commission of Fish and Fisheries, Part VIII. Report of the Commissioner for 1880, Appendix H. The oyster. Government Printing Office, Washington, DC (translated by H. J. Rice), p 683-751

NOAA (National Oceanic and Atmospheric Administration) (1997) 1995 National Shellfish Register, National Estuarine Inventory. NOAA, Washington, DC

NOAA CSC (National Oceanic and Atmospheric Administration Coastal Services Center) (2000) Willapa Bay, Washington Field Data Points, 1997. Geographic Information System (GIS) Electronic Map, Charleston, SC

Paine RT (2002) Trophic control of production in a rocky intertidal community. Science 296:736-739

Palacios R, Armstrong DA, Orensanz J (2000) Fate and legacy of an invasion: extinct and extant populations of the softshell clam (Mya arenaria) in Grays Harbor (Washington). Aquat Conserv Mar Freshw Ecosyst 10:279-303

Parker IM, Simberloff D, Lonsdale WM, Goodell K and 7 others (1999) Toward a framework for understanding the ecological effects of invaders. Biol Invest 1:3-19

Patten K (2003) Persistence and non-target impact of imazapyr associated with smooth cordgrass control in an estuary. J Aquat Plant Manag 41:1-5

Pawlak BT, Olson AM (1995) Policies and management practices of Washington state agencies as they pertain to the seagrasses Zostera marina and Zostera japonica: an ecological analysis. Puget Sound Res 2:516-521

Pennings SC, Richards CL (1998) Effects of wrack burial in salt-stressed habitats: Batis maritima in a southwest Atlantic salt marsh. Ecography 21:630-638

Peterson CD, Doyle DL, Barnett ET (2000) Coastal flooding and beach retreat from coseismic subsidence in the Central Cascadia Margin, USA. Environ Eng Geosci 6:255-269

Posey MH (1988) Community changes associated with the spread of an introduced seagrass, Zostera japonica. Ecology 69:974-983

Powell EN, Hofmann EE, Klinck JM, Ray SM (1992) Modeling oyster populations. 1. A commentary on filtration rate. Is faster always better? J Shellfish Res 11:387-398

Pritchard ES (ed) (2004) Fisheries of the United States 2003. National Marine Fisheries Service, Office of Science and Technology, Fisheries Statistics Division, Silver Spring, MD

Raffaelli D, Emmerson M, Solan M, Biles C, Paterson D (2003) Biodiversity and ecosystem processes in shallow coastal waters: an experimental approach. J Sea Res 49:133-141

Ranwell DS (1967) World resources of Spartina townsendii (sensu lato) and economic use of Spartina marshland. J Appl Ecol 4:239-256

Rosenzweig ML (2000) Biodiversity in equations. Recherche 333:68-70

Ruesink JL, Srivastava DS (2001) Numerical and per capita responses to species loss: mechanisms maintaining ecosystem function in a community of stream insect detritivores. Oikos 93:221-234

Ruesink JL, Roegner GC, Dumbauld BR, Newton JA, Armstrong DA (2003) Contributions of coastal and watershed 
energy sources to secondary production in a northeastern Pacific estuary. Estuaries 26:1079-1093

Ruesink JL, Lenihan HS, Trimble AC, Heiman KW, Micheli F, Byers JE, Kay M (2005) Introduction of non-native oysters: ecosystem effects and restoration implications. Annu Rev Ecol Evol Syst 36:643-689

Sax DF, Gaines SD, Brown JH (2002) Species invasions exceed extinctions on islands worldwide: a comparative study of plants and birds. Am Nat 160:766-783

Shea K, Chesson P (2002) Community ecology theory as a framework for biological invasions. Trends Ecol Evol 17:170-176

Simenstad CA, Jay DA, Sherwood CR (1992) Impacts of watershed management on land-margin ecosystems: the Columbia River estuary. In: Naiman RJ (ed) Watershed management: balancing sustainability and environmental change. Springer-Verlag, New York, p 266-306

Solan M, Cardinale BJ, Downing AL, Engelhardt KAM, Ruesink JL, Srivastava DS (2004) Extinction and ecosystem function in the marine benthos. Science 306: $1177-1180$

Solidoro C, Melaku Canu D, Rossi R (2003) Ecological and economic considerations on fishing and rearing of Tapes phillipinarum in the lagoon of Venice. Ecol Model 170: 303-318

Stachowicz JJ, Fried H, Osman RW, Whitlach RB (2002) Biodiversity, invasion resistance, and marine ecosystem function: reconciling pattern and process. Ecology 83: 2575-2590

Thom RM (1990) Spatial and temporal patterns in plant standing stock and primary production in a temperate seagrass system. Bot Mar 33:497-510

Townsend CH (1893) Report of observations respecting the oyster resources and oyster fishery of the Pacific coast of the United States. In: U.S. Fisheries Commission Report. Government Printing Office, Washington, DC, p 343-372

Townsend $\mathrm{CH}$ (1896) The transplanting of eastern oysters to Willapa Bay, Washington, with notes on the native oyster industry. In: U.S. Fisheries Commission Report. Government Printing Office, Washington, DC, p 193-202

Vitousek PM, Walker LR (1989) Biological invasions by Myrica faya in Hawaii: plant demography, nitrogen fixation, ecosystem effects. Ecol Monogr 59:247-265

WDF/WDOE (Washington Department of Fisheries/Washington Department of Ecology) (1992) Use of the insecticide

Editorial responsibility: Martin Solan (Guest Editor), Newburgh, UK carbaryl to control ghost and mud shrimp in oyster beds of Willapa Bay and Grays Harbor. Supplemental Environmental Impact Statement, Washington Department of Fisheries and Washington Department of Ecology, Olympia, WA

WADNR (Washington Department of Natural Resources) (1999) 1997 Spartina alterniflora infestation mapped on Willapa Bay, WA. Geographic Information System (GIS) Electronic Map, WADNR, Aquatic Resources Division, Olympia, WA

WADNR (Washington Department of Natural Resources) (2003) 2000 Spartina alterniflora infestation mapped on Willapa Bay, WA. Geographic Information System (GIS) Electronic Map, WADNR, Aquatic Resources Division, Olympia, WA

Webb AP, Eyre BD (2004) Effect of natural populations of burrowing thalassinidean shrimp on sediment irrigation, benthic metabolism, nutrient fluxes and denitrification. Mar Ecol Prog Ser 268:205-220

Wilcove DS, Rothstein D, Dubow J, Phillips A, Losos E (1998) Quantifying threats to imperiled species in the United States. BioScience 48:607-615

Williamson M, Fitter A (1996) The varying success of invaders. Ecology 77:1661-1666

Wolf EC (1993) A tidewater place: portrait of the Willapa ecosystem. Willapa Alliance, EcoTrust Publications, Long Beach, WA

Wonham MJ (2003) Ecological gambling: expendable extinctions versus acceptable invasions. In: Kareiva P, Levin SA (eds) The importance of species. University Press, Princeton, NJ, p 179-205

Wonham MJ, Carlton JT (2005) Trends in marine biological invasions at local and regional scales: the Northeast Pacific Ocean as a model system. Biol Invest 7:369-392

Zhang RS, Shen YM, Lu LY, Yan SG, Wang YH, Li JL, Zhang ZL (2004) Formation of Spartina alterniflora salt marshes on the coast of Jiangsu Province, China. Ecol Eng 23: 95-105

Zieman JC, Wetzel RG (1980) Productivity in seagrasses: methods and rates. In: Phillips RC, McRoy CP (eds) Handbook of seagrass biology: an ecosystem perspective. Garland STPM Press, New York, p 87-115

Zipperer VT (1996) Ecological effects of the introduced cordgrass, Spartina alterniflora, on the benthic community structure of Willapa Bay, Washington. MS thesis, University of Washington, Seattle, WA

Submitted: December 4, 2004; Accepted: October 21, 2005 Proofs received from author(s): March 9, 2006 